\title{
Przypadek kliniczny złośliwego nadciśnienia tętniczego z zespołem odwracalnej encefalopatii tylnej u pacjentki z toczniem rumieniowatym układowym oraz zespołem antyfosfolipidowym
}

\author{
Clinical case of malignant hypertension with posterior reversible \\ encephalopathy syndrome in a patient with systemic lupus erythematosus \\ and antiphospholipid syndrome
}

Agnieszka Stawicka, Grzegorz Skonieczny

Oddział Kardiologii i Intensywnego Nadzoru Kardiologicznego oraz Oddział Intensywnej Terapii Kardiologicznej Wojewódzkiego Szpitala Zespolonego im. L. Rydygiera w Toruniu

\section{Streszczenie}

Przedstawiono przypadek złośliwego nadciśnienia tętniczego u pacjentki z przełomem nadciśnieniowym powikłanym encefalopatią nadciśnieniową i zespołem odwracalnej encefalopatii tylnej. Przyczyną tego stanu okazała się choroba układowa - toczeń rumieniowaty układowy przebiegający z zajęciem ośrodkowego układu nerwowego, nerek, płuc i serca (choroba Libmana-Sacksa) oraz zespołem antyfosfolipidowym. W artykule opisano trudności w terapii choroby podstawowej, złośliwego nadciśnienia tętniczego, dyslipidemii oraz leczenie powikłań narządowych i prewencję dalszej progresji choroby.

Słowa kluczowe: encefalopatia nadciśnieniowa, toczeń rumieniowaty układowy, zespół antyfosfolipidowy

Folia Cardiologica 2017; 12, supl. B: B26-B29

\section{Wstęp}

Prewencja wtórna późna w swej definicji obejmuje działania terapeutyczne wobec osób z rozpoznaną chorobą, których celem jest zapobieżenie lub przynajmniej odsunięcie w czasie jej niekorzystnych następstw [1]. Nadciśnienie tętnicze oraz dyslipidemia u pacjentów, u których powikłania narządowe są zaawansowane (złośliwe nadciśnienie tętnicze) oraz towarzyszą im inne choroby odpowiedzialne za ich powstanie (nadciśnienie wtórne), stanowią problem istotny klinicznie. Zachodzi konieczność zastosowania politerapii, która naraża pacjenta na występowanie interakcji lekowych, działań niepożądanych, a także przyczynia się do nieprzestrzegania zaleceń lekarskich.

\section{Opis przypadku}

Pacjentka w wieku 38 lat została skierowana do szpitala z powodu zasłabnięcia, zaburzeń widzenia oraz duszności obserwowanej według relacji chorej od kilku dni. Pacjentka nie kontrolowała się u lekarza rodzinnego, nie leczyła się z powodu chorób przewlekłych. W wywiadzie stwierdzono 3 ciąże, 2-krotne incydenty utraty ciąży (w 16. i 20. tygodniu). W trakcie ciąż rozpoznawano nadciśnienie ciążowe niepowikłane stanem przedrzucawkowym czy rzucawką. Chora negowała używki (paliła papierosy w przeszłości). Pacjentka prezentowała trudności w skupieniu uwagi oraz formułowaniu odpowiedzi na pytania. W badaniu przedmiotowym z odchyleń od normy obserwowano war- 


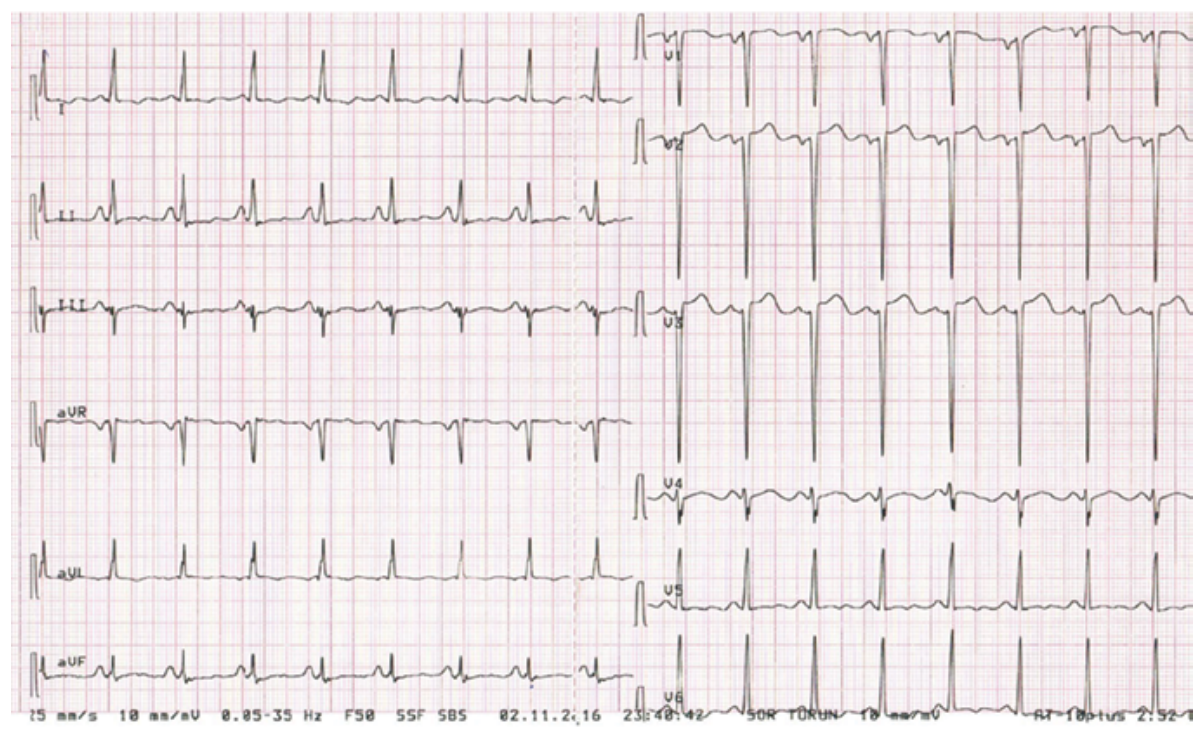

Rycina 1. Zapis elektrokardiograficzny: miarowy rytm zatokowy 78/min, oś pośrednia, zmiany odcinka ST-T w odprowadzeniach I, II, aVL i V5-V6 - widoczne cechy przerostu lewego przedsionka i lewej komory

tości ciśnienia około 230/140 mm Hg, śladowe obrzęki kończyn dolnych. Wykonano zapis elektrokardiograficzny (EKG) (ryc. 1) oraz przeprowadzono badania laboratoryjne (tab. 1). W angiografii tomografii komputerowej klatki piersiowej bez cech zatorowości płucnej stwierdzono obszary zagęszczeń miąższowych o typie mlecznej szyby, niewielką ilość płynu w prawej jamie opłucnowej. Pacjentkę przyjęto na oddział kardiologiczny z rozpoznaniem wstępnym przełomu nadciśnieniowego z objawami niewydolności serca. W badaniu echokardiograficznym (ECHO) serca stwierdzono powiększony lewy przedsionek, koncentrycznie pogrubiały mięsień lewej komory ze wzmożoną echogenicznością, upośledzoną funkcję skurczową lewej komory z uogólnioną hipokinezą (frakcja wyrzutowa [EF, ejection fraction] 40-45\%), umiarkowaną niedomykalność mitralną, małą separację osierdzia (ryc. 2). W badaniu ultrasonograficznym (USG) obraz nerek sugerujący przewlekłe zmiany zapalne, w konsultacji okulistycznej obraz angioretinopatii nadciśnieniowej III stopnia obu oczu. W rezonansie magnetycznym (MRI, magnetic resonance imaging) głowy (ryc. 3) stwierdzono zmiany naczyniopochodne między innymi w okołokomorowej istocie białej obu półkul, rozsiane ogniska hiperintensywne w obrazowaniu T2-zależnym, gęstości protonów (PD, proton density) i sekwencji inwersji i powrotu (FLAIR, fluid attenuated inversion recovery) oraz izointensywne w obrazowaniu T1-zależnym. Ogniska o charakterze świeżych zmian niedokrwiennych, położone podkorowo, w płacie potylicznym lewym, w okolicy czołowej lewej, kilka zmian w prawym płacie potylicznym, liczne ogniska w obu płatach czołowych i ciemieniowych oraz pojedyncze w lewej półkuli móżdżku. W badaniu neurologicznym oraz psychologicznym stwierdzono obustronne objawy pirami- dowe i znaczne ubytki funkcji poznawczych, ze znacznymi zaburzeniami w zakresie gnozji wzrokowej. Na podstawie obrazu klinicznego, badań obrazowych i immunologicznych ustalono rozpoznanie tocznia układowego (SLE, systemic lupus erythematosus) z zajęciem ośrodkowego układu nerwowego (OUN), nerek, serca i płuc oraz zespołu antyfosfolipidowego.

\section{Omówienie}

U pacjentki rozpoznano tak zwany stan nagły związany ze złośliwym nadciśnieniem tętniczym z zagrażającymi lub postępującymi uszkodzeniami narządowymi. Obecnie nadciśnienie złośliwe jest rzadko rozpoznawane z uwagi na rozpowszechnione leczenie hipotensyjne [2]. Zaburzenia ze strony układu sercowo-naczyniowego występują u ponad 50\% pacjentów z SLE. Obraz badania ECHO serca odpowiadał chorobie Libmana-Sacksa, która występuje u około 10\% pacjentów z SLE. Zmiany dotyczą najczęściej zastawki mitralnej (63\%) i prowadzą zwykle do łagodnej niedomykalności, z reguły niewymagającej leczenia kardiochirurgicznego (75\%) [3]. Specyficzne zmiany w MRI odpowiadały nadciśnieniu z zespołem odwracalnej encefalopatii tylnej (PRES, posterior reversible encephalopathy syndrome) [4]. Leczenie pacjentki kontynuowano na oddziale chorób wewnętrznych, gdzie włączono metyloprednizolon i cyklofosfamid. Ze względu na zmiany na dnie oka odroczono podanie chlorochiny. Po zastosowaniu intensywnej steroidoterapii wartości ciśnienia tętniczego stopniowo ulegały normalizacji i uzyskano poprawę stanu ogólnego chorej. U pacjentów z chorobą autoimmunologiczną obserwuje się nasilenie miażdżycy oraz większą chorobowość i umieralność z przy- 
Tabela 1. Badania laboratoryjne

\begin{tabular}{|c|c|c|c|}
\hline Parametr & Wartość & Zakres normy & Jednostka \\
\hline Stężenie kreatyniny & 1,37 & $0,51-0,95$ & $\mathrm{mg} / \mathrm{dl}$ \\
\hline Wartość eGFR & 38,87 & $\geq 90$ & $\mathrm{ml} / \mathrm{min} / 1,73 \mathrm{~m}^{2}$ \\
\hline Stężenie białka w moczu & 2,88 & $0,01-0,14$ & $g / l$ \\
\hline Stężenie białka w moczu dobowym & 0,83 & 0,15 & $\mathrm{~g} / \mathrm{d}$ \\
\hline Stężenie cholesterolu całkowitego & 273 & $<190$ & $\mathrm{mg} / \mathrm{dl}$ \\
\hline Stężenie cholesterolu frakcji HDL & 54,1 & $>45$ & $\mathrm{mg} / \mathrm{dl}$ \\
\hline Stężenie cholesterolu frakcji LDL & 187 & $<115,0$ & $\mathrm{mg} / \mathrm{dl}$ \\
\hline Stężenie triglicerydy & 162 & $<150$ & $\mathrm{mg} / \mathrm{dl}$ \\
\hline Stężenie troponiny I ultra & 0,085 i po 3 h 0,173 & $<0,04$ & $\mu \mathrm{g} / \mathrm{l}$ \\
\hline Stężenie NT-proBNP & 16616 & $<110$ & $\mathrm{pg} / \mathrm{ml}$ \\
\hline Stężenie D-dimerów & 2,89 & $<0,5$ & $\mu \mathrm{g} / \mathrm{l}$ \\
\hline Miano przeciwciał antykardiolipinowych lgG & 101,04 & $<12$ & PLI gG-U/ml \\
\hline Miano przeciwciał przeciw $\beta_{2}$-glikoproteinie lgG & 52,32 & $<20,0$ & $\mathrm{RU} / \mathrm{ml}$ \\
\hline ANA (IF test przesiewowy) & Dodatni & $\begin{array}{c}<1: 160 \text { ujemny } \\
\text { (typ fluorescencji homogenny, } \\
\text { miano 1:3200) }\end{array}$ & \\
\hline ANA PM-Scl & Dodatni & & \\
\hline ANA dsDNA & Dodatni & & \\
\hline ANA nukleosomy & Dodatni & & \\
\hline ANA AMA-M2 & Dodatni & & \\
\hline ANCA & Dodatni & $\begin{array}{l}<1: 10 \text { ujemny } \\
\text { (miano } 1: 100 \text { ) }\end{array}$ & \\
\hline
\end{tabular}

eGFR (estimated glomerular filtration rate) - szacowana filtracja kłębuszkowa; HDL (high-density liporoteins) - lipoproteiny o wysokiej gęstości; LDL (Iow-density liporoteins) - lipoproteiny o niskiej gęstości; NT-proBNP ( $N$-terminal fragment of prohormone B-type natriuretic peptide) - N-końcowy fragment propeptydu natriuretycznego typu B; IgG - immunoglobuliuna G; IF (immunofluorescence) - metoda immunofluorescencji; ANA (antinuclear antibody) - przeciwciało przeciwjądrowe; ANCA (anti-neutrophil cytoplasmic antibodies) - przeciwciała przeciw cytoplazmie granulocytów obojętnochłonnych

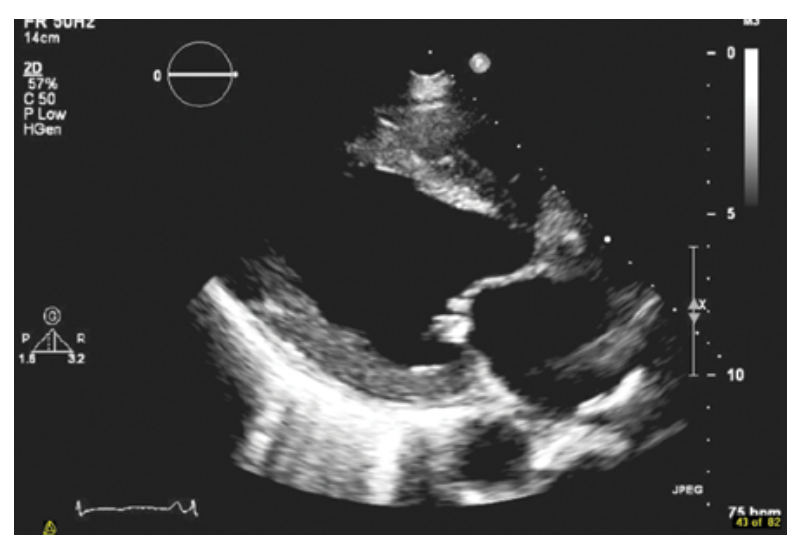

Rycina 2. Badanie echokardiograficzne serca w projekcji przymostkowej w osi długiej - widoczna organicznie zmieniona zastawka mitralna czyn sercowo-naczyniowych. W tych przypadkach leczenie statynami obniża ryzyko występowania incydentów sercowo-naczyniowych oraz umieralność (zwłaszcza w prewencji pierwotnej). Nie ma jednak jednoznacznych wskazań do leczenia wynikających z samej obecności choroby autoimmunologicznej, nie ustalono również docelowych wartości stężenia cholesterolu frakcji LDL (low-density lipoprotein). W tych przypadkach należy brać pod uwagę indywidualne ryzyko choroby sercowo-naczyniowej [5]. Z uwagi na planowaną kontynuację steroidoterapii oraz na narastającą niewydolność nerek (stadium G3b) podjęto decyzję o odroczeniu leczenia hipolipemizującego na okres najintensywniejszej fazy leczenia i zalecono pacjentce diete. Podczas wypisu zalecono stosowanie: karwedilolu, nitrendipiny, ramiprilu, doksazosyny, torasemidu, pantoprazolu, prednizolonu, 


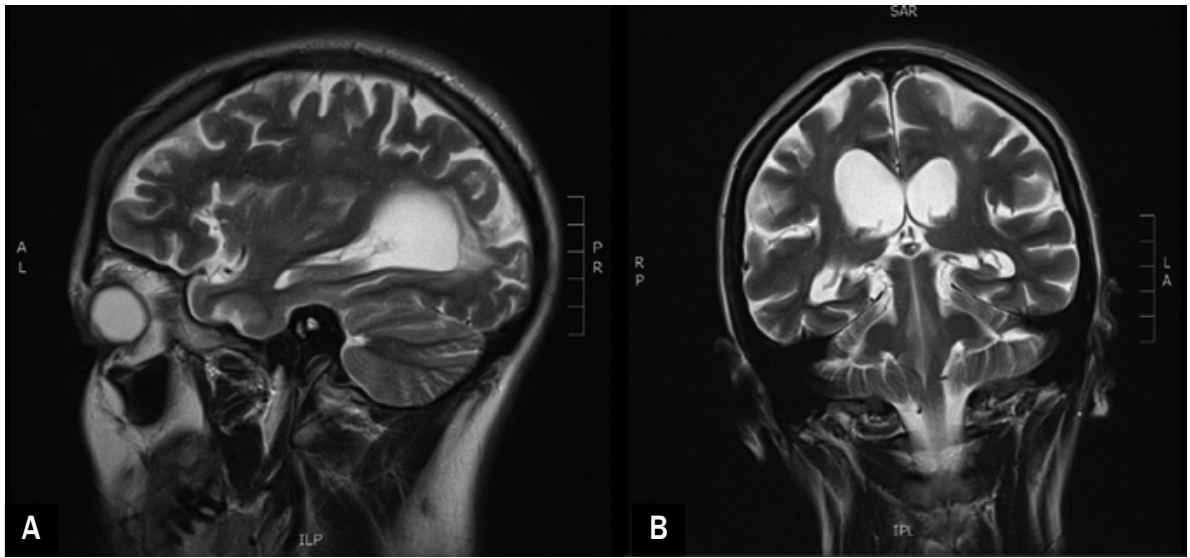

Rycina 3A, B. Badanie rezonansu magnetycznego głowy - widoczne rozsiane ogniska hiperintensywne w sekwencji T2-zależnej

kwasu acetylosalicylowego oraz enoksaparyny. Podczas jednej z kolejnych hospitalizacji, po około 3 miesiącach, wykonano ponownie badanie MRI głowy. W badaniu bez ognisk restrykcji dyfuzji zmiany niedokrwienne opisywane w pierwszym badaniu uległy ewolucji - nie uwidoczniono opisywanych poprzednio zmian w moście i półkuli móżdżku. W okołokomorowej istocie białej obu półkul oraz podkorowo nadal utrzymywały się rozsiane ogniska hiperintensywne. Świeże zmiany niedokrwienne w pierwszym badaniu i ich regresja w drugim oraz ustąpienie zaburzeń poznawczych obserwowanych podczas pierwszej hospitalizacji przemawiają za obrazem encefalopatii nadciśnieniowej. Natomiast utrwalone zmiany w MRI można wiązać z chorobą podstawową, w tym przypadku z SLE.

\section{Konflikt interesów}

Nie zgłoszono.

\section{Abstract}

A case of malignant hypertension in patient with hypertensive crisis complicated by hypertensive encephalopathy and posterior reversible encephalopathy syndrome. The reason for this state was a systemic disease - lupus erythematosus extending with the involvement of central nervous system, kidneys, lungs, heart (Libman-Sacks disease) and antiphospholipid syndrome. In this article difficulties in the treatment of the underlying disease, malignant hypertension, dyslipidemia, and treatment of organ damage and prevention of further disease progression were described.

Key words: hypertensive encephalopathy, systemic lupus erythematosus, antiphospholipid syndrome

Folia Cardiologica 2017; 12, supl B: B26-B29

\section{Piśmiennictwo}

1. Tykarski A, Narkiewicz K, Gaciong Z, et al. Zasady postępowania w nadciśnieniu tętniczym - 2015 rok. Nadciśnienie Tętnicze w Praktyce. 2015; 1(1): 1-70.

2. ESC E. Grupa Robocza Europejskiego Towarzystwa Nadciśnienia Tętniczego (ESH) i Europejskiego Towarzystwa Kardiologcznego (ESC) do spraw postępowania w nadciśnieniu tętniczym. Wytyczne ESH/ ESC dotyczące postępowania w nadciśnieniu tętniczym w 2013 roku. Nadciśnienie Tętnicze. 2013; 17(2): 69-168.

3. Woynarowska A, Wojciechowska M, Cudnoch-Jędrzejewska A, et al. Choroby układu sercowo-naczyniowego $w$ toczniu rumieniowatym układowym. Kardioprofil. 2016; 14(3-4): 55-56.
4. Hinchey J, Chaves C, Appignani B, et al. A reversible posterior leukoencephalopathy syndrome. N Engl J Med. 1996; 334(8): 494500, doi: 10.1056/NEJM199602223340803, indexed in Pubmed: 8559202.

5. Catapano A, Graham I, De Backer G, et al. [2016 ESC/EAS Guidelines for the Management of Dyslipidaemias]. Kardiol Pol. 2016; 74(11): 1234-1318, doi: 10.5603/kp.2016.0157, indexed in Pubmed: 27910077. 